\section{CALCULATION OF RANGES, ETC., OF ELONGATED PROJECTILES.}

F ROM time to time it has been suggested to me that some reduction in the coefficients of resistance deduced from my experiments made in $1867-68$, is required to adapt them for use in connection with the improved guns of more recent times. I do not agree with those suggestions. My coefficients were most carefully deduced from experiments made with ogival-headed shot fired at very low elevations so as to secure ranges of about 500 or 600 yards, and the observations were made near the gun. The 5-inch gun was a remarkably good gun, and from the numerous records it gave had a preponderating effect on the final result; while an unsteady shot cut only a few screens, and had a very trifling influence. It seems, therefore, that the coefficients were derived from shot moving very nearly in the direction of their axes. I have applied these coefficients to calculate ranges for comparison with Commander May's (R.N.) range-table for the 12-inch muzzleloading gun (based on practice 1885); muzzle velocity, I 892 f.s. ; " jump," 6 minutes.

\begin{tabular}{|c|c|c|c|c|c|c|}
\hline $\begin{array}{c}\text { Elevation } \\
\text { Exp. range }\end{array}$ & $\ldots$ & $\begin{array}{c}x^{\circ} \\
I 200\end{array}$ & $\begin{array}{c}2^{0} \\
2267\end{array}$ & $\begin{array}{r}3^{\circ} \\
3200\end{array}$ & $\begin{array}{r}4^{\circ} \\
4057\end{array}$ & 7 yard \\
\hline Calc. range & $\cdots$ & 1206 & 2249 & 3192 & $\begin{array}{l}4031 \\
4039\end{array}$ & 9 , \\
\hline Differ & .. & +6 & -18 & -8 & -18 & \\
\hline
\end{tabular}

I will now do the same for the 4-inch breech-loading gun, which was the gun chosen by the authorities to be used in testing my coefficients on a long range; muzzle velocity, 1900 f.s. ; range-table founded on experiments made in 1884 ; "jump," 6 minutes.

$\begin{array}{ccccccc}\text { Elevation } & & 1^{\circ} & 2^{\circ} & 3^{\circ} & 4^{\circ} & \\ \text { Exp. range } & \ldots & 1086 & 1811 & 2400 & 2917 & \text { yards. } \\ \text { Calc. range } & \ldots & 1049 & 1817 & 2410 & 2895 & \text { 10 } \\ \text { Difference } & \ldots & -37 & +6 & \text { +10 } & -22 & -2\end{array}$

Thus it appears that my coefficients give very satisfactory results when applied under the conditions of the original experiments. Commander May's table stops at a range of 4000 yards. As the elevation of the 4 -inch gun was gradually increased, the calculated ranges fell shorter and shorter of the experimental ranges. At an elevation of $15^{\circ}$ the calculated range was 6364 yards, and the experimental range 6608 yards, giving a difference of 244 yards. The explanation of this seems to me to be as follows :-

When an elongated shot is fired from a rifled gun at high elevations, the shot endeavours to preserve the parallelism of its axis. This causes the axis of the shot to become sensibly inclined to the direction of the motion of its centre of gravity. Thus the pressure of the air acts from below and raises the shot bodily, so as to give its trajectory an increased elevation. This would naturally increase the range of the shot. After a short time the shot inclines sideways, as explained by Magnus, and the shot continues to move with its axis inclined to the direction of its motion, which is the cause of the lateral "drift" of the shot. This shot having had its axis so much inclined to the direction of its motion, would encounter a greater resistance from the air than another shot fired at a lower elevation, because this latter would move with its axis more nearly in the direction of its motion.

Hence it is clear that, in order to aprly any rational correction to the calculated ranges for high elevations, it would be necessary slightly to increase both ( 1 ) the elevation, and (2) the values of the coefficients of resistance.

Major Mackinlay, R.A., warns us that the published range-tables are not to be "blindly followed," a very necessary caution, when it is considered that we cannot be quite certain about the muzzle velocity, the "jump," the elevation, and the precise form of the head. The height of the barometer is seldom mentioned. My only sur- prise is that such good agreement between calculation and experiment should be found as above. The only question seems to be whether it is worth while to trouble about the correction of calculated ranges for high velocities and high elevations, when the reason for some little discrepancy is so evident. But to reduce coefficients would be to make matters worse.

Having been requested to calculate the range of a 9.2inch shot weighing 380 pounds, fired at an elevation of $40^{\circ}$ with a muzzle velocity of 2360 f.s., I could not feel satisfied till I had completed the calculation of a range-table for elevations $0^{\circ}$ to $45^{\circ}$ on a horizontal plane 27 feet below the muzzle. I give the result. Gravity and the temperature of the air were considered constant. The air was supposed to be at rest, and the shot was assumed to move in the direction of its axis; head ogival, struck with a radius of $\mathrm{I}_{2} \frac{1}{2}$ diameter. When the results of experiment are published I shall be ready to discuss the matter, but there are so many things uncertain at heights of I0,000, I5,000 feet, \&c.. that I doubt whether any theoretical advantages will result. It will, however, be interesting to know what can be done in an extremity.

It will be seen that the ranges go on increasing up to an elevation of $45^{\circ}$, and would probably go on beyond an elevation of $50^{\circ}$ before reaching a maximum.

\begin{tabular}{|c|c|c|c|c|c|c|}
\hline Elevation. & & $\begin{array}{l}\text { Height } \\
\text { of } \\
\text { Verrex. }\end{array}$ & $\begin{array}{c}\text { Time } \\
\text { of } \\
\text { Flight. }\end{array}$ & $\begin{array}{c}\text { Angle } \\
\text { of } \\
\text { Descent. }\end{array}$ & $\begin{array}{c}\text { Striking } \\
\text { Velocity. }\end{array}$ & $\begin{array}{c}\text { Horizontal } \\
\text { Striking } \\
\text { Velocity. }\end{array}$ \\
\hline$\stackrel{\circ}{\circ}$ & $\begin{array}{c}\text { Yards. } \\
969\end{array}$ & $\begin{array}{c}\text { Feet. } \\
\text { o }\end{array}$ & $\begin{array}{c}\text { Seconds. } \\
1 \cdot 3\end{array}$ & I 4 & $\begin{array}{c}\text { f.s. } \\
2, \mathrm{I} 54\end{array}$ & $\begin{array}{l}\text { y.s. } \\
718\end{array}$ \\
\hline I & $2, \operatorname{Ir} 5$ & 25 & 30 & I 35 & I,93I & 643 \\
\hline 2 & 3,416 & 94 & $5 \cdot I$ & 247 & $\mathrm{r}, 708$ & 569 \\
\hline 3 & 4,6 II & 237 & $7^{\circ} \mathrm{I}$ & 420 & I, 528 & 508 \\
\hline $\begin{array}{l}4 \\
5\end{array}$ & $\begin{array}{l}5,600 \\
6,475\end{array}$ & $\begin{array}{l}343 \\
5 \mathrm{I} 7\end{array}$ & $\begin{array}{r}9.4 \\
\times 14\end{array}$ & $\begin{array}{ll}5 & 52 \\
7 & 38\end{array}$ & $\begin{array}{l}1,399 \\
1,291\end{array}$ & $\begin{array}{l}464 \\
426\end{array}$ \\
\hline 6 & $7,27 \mathrm{I}$ & 716 & 13.4 & 930 & 1,203 & 395 \\
\hline 7 & 7,999 & 937 & $15 \cdot 3$ & II 28 & I, 128 & 368 \\
\hline 8 & 8,669 & 1,180 & $17 \cdot \mathrm{I}$ & 1328 & r,o75 & 349 \\
\hline 9 & $9,29 \mathrm{I}$ & $I, 445$ & $18 \cdot 9$ & I5 28 & 1,040 & 334 \\
\hline IO & 9,876 & $\mathrm{I}, 73 \mathrm{I}$ & $20 \cdot 6$ & 1723 & 1,022 & 325 \\
\hline I I & Io, 430 & 2,036 & $22 \cdot 3$ & 199 & ז,015 & 320 \\
\hline I 2 & 10,952 & 2,360 & $23^{\circ} 9$ & 2054 & 1,009 & 314 \\
\hline I 3 & I I, 448 & 2,703 & $25^{\circ} 5$ & 2238 & 1,003 & 309 \\
\hline$x_{4}$ & 11,922 & 3,065 & $27^{\circ} \mathrm{O}$ & 2421 & 998 & 303 \\
\hline 15 & I2,379 & 3,443 & 28.5 & 262 & 993 & 297 \\
\hline I6 & 12,804 & 3.835 & $30^{\circ} \circ$ & 2740 & 990 & 292 \\
\hline I7 & 13,217 & 4,242 & $3 \mathrm{I} \cdot 5$ & $29 \times 5$ & 987 & 287 \\
\hline 18 & × 3,618 & 4,663 & $33^{\circ} 0$ & 3048 & 985 & 282 \\
\hline 19 & 14,007 & 5,099 & 34.4 & 3219 & 984 & 277 \\
\hline 20 & 14,385 & 5,550 & 35.9 & 3348 & 984 & 273 \\
\hline $2 I$ & $\times 4,750$ & 6,015 & $37 \cdot 3$ & $35 \quad 15$ & 985 & 268 \\
\hline 22 & I 5, IO3 & 6,489 & $38 \cdot 8$ & $3^{6} 40$ & 987 & 264 \\
\hline 23 & 15,445 & 6,970 & $40 \cdot 2$ & $3^{8} 3$ & 990 & 260 \\
\hline 24 & $\times 5,775$ & 7,459 & $4 r \cdot 6$ & 3924 & 993 & 256 \\
\hline 25 & 16,092 & 7,956 & $43^{\circ} \mathrm{O}$ & $404 \mathrm{I}$ & 996 & 252 \\
\hline 26 & 16,398 & $8,46 \mathrm{r}$ & 44.4 & 4154 & $\mathrm{I}, \infty 00$ & 248 \\
\hline 27 & 16,691 & 8,974 & $45 \cdot 7$ & 432 & I,004 & 245 \\
\hline 28 & 16,973 & 9,494 & $47 \cdot I$ & 446 & 1,009 & 242 \\
\hline 29 & 17,242 & 10,022 & $48 \cdot 4$ & 457 & 1,014 & 239 \\
\hline 30 & 17,501 & $10,55^{8}$ & 497 & $46 \quad 5$ & 1,019 & 236 \\
\hline $3 \mathrm{I}$ & 17,747 & I I , IO2 & $5 \mathrm{I}^{\circ} \mathrm{O}$ & $47 \mathrm{I}$ & 1,025 & 233 \\
\hline 32 & $\mathbf{1} 7,98 \mathbf{r}$ & 11,654 & $52 \cdot 2$ & 4756 & $\mathrm{I}, 03 \mathrm{I}$ & 230 \\
\hline 33 & 18,203 & 12,214 & 53.5 & 4850 & $\mathrm{x}, 037$ & 228 \\
\hline 34 & $18,4 \mathrm{I} 3$ & 12,782 & 547 & 4943 & $\mathrm{I}, 044$ & 225 \\
\hline 35 & 18,612 & 13,357 & $56 \%$ & 5035 & $1,05 \mathrm{I}$ & 222 \\
\hline 36 & $\mathbf{1 8 , 7 9 9}$ & I $3,94 \mathrm{I}$ & $57 \cdot 2$ & $5 \times 27$ & 1,058 & 220 \\
\hline 37 & 18,973 & 14,534 & $58 \cdot 5$ & 5218 & $x, 065$ & 217 \\
\hline 38 & 19,136 & 15,136 & $59 \cdot 7$ & 538 & $\mathrm{I}, 072$ & 214 \\
\hline 39 & 19,287 & 15,747 & 610 & $535^{8}$ & I,079 & 212 \\
\hline 40 & $\mathbf{1 9 , 4 2 6}$ & $x 6,368$ & $62 \cdot 2$ & 5447 & I, 086 & 209 \\
\hline 41 & $\times 9,553$ & 17,001 & 63.4 & 5536 & 1,092 & 206 \\
\hline 42 & 19,668 & 17,646 & 647 & 5624 & 1,099 & 203 \\
\hline 43 & 19,772 & 18,302 & 659 & 57 I I & $\mathrm{I}, \mathrm{I05}$ & 200 \\
\hline 44 & 19,864 & 18,969 & $67 \cdot I$ & 5757 & $\mathbf{I}, \mathrm{I} X \mathrm{X}$ & 197 \\
\hline 45 & I9,944 & 19,648 & $68 \cdot 3$ & $5^{8} 43$ & 1,117 & 193 \\
\hline
\end{tabular}

